\title{
PENGARUH MEDIA PEMBELAJARAN DAN KREATIVITAS TERHADAP KEMAMPUAN MENULIS HURUF PESERTA DIDIK TAMAN KANAK-KANAK
}

\author{
Ayong $^{1}$ dan Keysar Panjaitan ${ }^{2}$ \\ TK Dr. Wahidin Sudirohusodo, Medan ${ }^{1}$ dan Universitas Negeri Medan ${ }^{2}$ \\ yong_xyz@yahoo.co.id ${ }^{l}$
}

\begin{abstract}
Abstrak: Penelitian ini bertujuan untuk mengetahui: (1) Kemampuan menulis huruf anak TK yang diajarkan melalui tepung huruf lebih tinggi daripada melalui kartu huruf; (2) Kemampuan menulis huruf anak TK yang memiliki tingkat kreativitas tinggi lebih tinggi daripada memiliki tingkat kreativitas rendah; dan (3) Interaksi antara penggunaan media pembelajaran dan kreativitas terhadap kemampuan menulis huruf anak TK. Metode penelitian menggunakan penelitian eksperimen sетu (quasi experiment). Instrumen yang digunakan dalam penelitian ini adalah tes kemampuan menulis huruf dan tes kreativitas. Analisis data yang digunakan adalah ANAVA Faktorial $2 \times 2$. Hasil penelitian adalah: (1) hasil belajar kemampuan menulis huruf peserta didik kelas media pembelajaran tepung huruf lebih tinggi dengan kemampuan menulis huruf peserta didik kelas media pembelajaran kartu huruf dengan $F_{\text {hitung }}>F_{\text {tabel }}(4,042>3,94)$; (2) hasil belajar dengan kemampuan menulis huruf peserta didik yang memiliki kreativitas tinggi lebih tinggi dengan kemampuan menulis huruf peserta didik yang memiliki kreativitas rendah dengan $F_{\text {hitung }}>$ $F_{\text {tabel }}(42,024>3,94)$; dan (3) ada interaksi antara media pembelajaran dan kreativitas terhadap kemampuan menulis huruf dengan $F_{\text {hitung }}>F_{\text {tabel }}(7,172>3,94)$.
\end{abstract}

Kata Kunci: Media pembelajaran, Kreativitas, Kemampuan menulis huruf

Abstract: This study aims to determine: (1) The ability to write letters kindergarten children are taught through letters flour is higher than the card letters; (2) The ability to write letters kindergarten children who have high creativity levels higher than have lower levels of creativity; and (3) the interaction between the use of instructional media and creativity of the ability to write letters kindergarten children. The research method using quasi-experimental research (quasi experimental). The instrument used in this study is to test the ability to write letters and creativity test. Analysis of the data used is the $2 \times 2$ factorial ANOVA results are: (1) the learning outcomes of learners the ability to write letters media class higher learning letters flour with the ability to write letters of learners classroom instructional media card with the letter Fc > Ft (4.042 > 3.94); (2) the learning outcomes with the ability to write letters of learners who have a higher high creativity with the ability to write letters of learners who have low creativity with Fc > Ft (42.024 > 3.94); and (3) there is an interaction between media learning and creativity on the ability to write letters to the $F c>F t(7.172>3.94)$.

Keywords: Instructional media, Creativity, Writing ability

\section{PENDAHULUAN}

Usia 4 - 6 tahun merupakan masa peka yang penting bagi anak untuk mendapatkan pendidikan. Pengalaman yang diperoleh anak dari lingkungan, termasuk stimulasi yang diberikan oleh orang dewasa, akan mempengaruhi kehidupan anak di masa yang akan datang. Oleh karena itu, diperlukan upaya yang mampu memfasilitasi anak dalam masa tumbuh kembangnya berupa kegiatan pendidikan dan pembelajaran sesuai dengan usia, kebutuhan dan minat anak.
Undang-Undang Nomor 20 Tahun 2003 tentang Sistem Pendidikan Nasional Pasal 1 menyatakan bahwa Pendidikan Anak Usia Dini adalah suatu upaya pembinaan yang ditujukan kepada anak sejak lahir sampai dengan usia enam tahun yang dilakukan melalui pemberian rangsangan pendidikan untuk membantu pertumbuhan dan perkembangan jasmani dan rohani agar anak memiliki kesiapan dalam memasuki pendidikan lebih lanjut. Lebih lanjut pada Pasal 28 ayat 3 dinyatakan bahwa Taman Kanak-Kanak (TK) merupakan pendidikan anak 
usia dini pada jalur pendidikan formal. Sementara itu sebagai tindak lanjut dikeluarkannya Peraturan Pemerintah Nomor 17 Tahun 2010 tentang Pengelolaan dan Penyelenggaraan Pendidikan; serta Peraturan Menteri Pendidikan Nasional Nomor 58 Tahun 2009 tentang Standar Pendidikan Anak Usia Dini, maka Direktorat Pembinaan TK dan SD telah menyusun Naskah Seri Pembinaan Kurikulum di TK.

Proses pendidikan merupakan suatu proses berkelanjutan sejak dalam kandungan sampai pada akhir hayat manusia. Silberman dalam Hamid (2011:48) mengemukakan belajar bukan merupakan konsekuensi otomatis dari penyampaian informasi kepada anak. Sebab, pada dasarnya belajar membutuhkan mental sekaligus tindakan. Hal ini juga dikemukakan oleh Bloom dalam Dryden dan Vos (2001:79) bahwa sekitar 50\% kemampuan belajar seseorang yang diukur dengan tes pada usia tujuh belas tahun, terbentuk pada masa pembuahan sampai empat tahun, sekitar 30\% antara empat sampai delapan tahun, dan $20 \%$ terakhir antara usia delapan sampai tujuh belas tahun. Berdasarkan hal ini dapat dikemukakan bahwa masa usia dini merupakan periode yang sangat penting dalam pembentukan dan pengembangan kognitif seseorang saat dewasa. Biasanya orang akan menamakan masa tersebut sebagai masa keemasan (golden age) anak karena pada masa itulah anak mudah menyerap apa yang disampaikan maupun yang diajarkan.

Hakikat belajar yang dikemukakan oleh Hamid (2011:115) bahwa manusia dapat belajar melalui enam tingkatan yaitu: $10 \%$ dari yang dibaca, $20 \%$ dari yang didengar, $30 \%$ dari yang dilihat, $50 \%$ dari yang dilihat dan didengar, $70 \%$ dari yang dikatakan, dan $90 \%$ dari yang dikatakan dan dilakukan. Menurut Peoples dalam Aqib (2013:48) seluruh pengetahuan yang diperoleh didapat dari: $75 \%$ dari melihat, $13 \%$ dari mendengar, dan $12 \%$ dari mengecap, mencium dan meraba. Usman dalam Hamid (2011:207) mengemukakan bahwa pembelajaran merupakan sebuah proses yang mengandung serangkaian perbuatan guru dan anak atas dasar hubungan timbal balik, yang berlangsung dalam situasi edukatif untuk mencapai tujuan tertentu. Adapun yang termasuk dalam komponen pembelajaran adalah tujuan, bahan, metode, alat, dan penilaian (Sudjana, 1998:30).

Taman Kanak-kanak (TK) merupakan suatu wadah pendidikan anak usia dini. Dalam
TK, anak akan diberikan kegiatan belajar untuk membentuk dan mengembangkan perilaku serta kemampuan dasar yang meliputi kemampuan berbahasa, daya pikir, daya cipta, keterampilan, dan jasmani. Snowman yang dikutip oleh Patmonodewo (2003) menjelaskan ciri-ciri prasekolah (3 - 6 tahun) yang biasanya ada di Taman Kanak-Kanak (TK). Ciri-ciri yang dikemukakan meliputi aspek fisik, sosial, emosi, dan kognitif anak. Hal ini mengingat kompetensi dasar yang harus dimiliki setiap anak sebagaimana tertuang dalam tujuan kurikulum TK yakni membantu anak didik mengembangkan berbagai potensi baik psikis dan fisik yang meliputi moral dan nilai-nilai agama, sosial emosional, kognitif, bahasa, fisik/ motorik, kemandirian dan seni untuk siap memasuki pendidikan dasar. Program pembelajaran di TK diarahkan pada pencapaian perkembangan anak yang sesuai dengan pertumbuhan dan perkembangan anak berdasarkan tingkat pencapaian perkembangan anak yang dikategorikan dalam kelompok umur 4 - 6 tahun sebagai acuan normatif dan dikembangkan untuk mempersiapkan peserta didik agar siap mengikuti pendidikan pada jenjang SD/MI.

Bermain bagi anak-anak TK merupakan kegiatan yang dipengaruhi oleh berbagai aspek. Aspek-aspek tersebut berpengaruh terhadap bentuk dan jenis permainan yang akan dilakukan anak tersebut. Tentunya bentuk dan jenis permainan tersebut merupakan wahana bagi peningkatan aspek-aspek pengembangan anak, yaitu fisik, kognitif, bahasa, sosial emosi, moral dan nilai-nilai agama serta seni. Teori Piaget dalam Seefeldt dan Barbara (2008:23) mengemukakan bahwa permainan adalah proses berpikir. Permainan adalah jalan bagi anak-anak mengembangkan kemampuan menggunakan lambang dan memahami lingkungan mereka. Kegiatan bermain bagi anak adalah kegiatan yang serius tapi menyenangkan. Fadillah (2012:168) menyatakan bermain adalah suatu kegiatan yang dilakukan untuk kesenangan yang ditimbulkannya, tanpa mempertimbangkan hasil akhir. Bermain adalah salah satu kesukaan mayoritas anak usia dini. Secara normal tidak ada seorang anakpun yang tidak suka bermain. Semua anak suka bermain, meskipun sifatnya sangat sederhana. Sedangkan Semiawan (2002:47) mengungkapkan bahwa bermain adalah aktivitas yang dipilih sendiri oleh anak karena menyenangkan bukan karena hadiah ataupun pujian. Dengan bermain secara 
bebas anak akan dapat mengembangkan semua potensi mental dan fisik yang dimilikinya. Oleh karena itu bermain bagi anak TK merupakan jembatan emas bagi tumbuh kembangnya aspek jasmani dan rohani yang dimilikinya.

Pada dasarnya pelaksanaan pendidikan di TK, menganut prinsip bermain sambil belajar (unsur bermain lebih besar dan dominan) dan belajar seraya bermain. Kalimat belajar sambil bermain, bermain seraya belajar sebagai slogan yang lancar diucapkan para guru di lembaga PAUD. Seefeldt dan Nita (1994:313) mengemukakan: "balancing play with work, therefore, becomes an important framework for developing curriculum and learning environments for children. With an understanding of the theories and stages of children's play and the interaction of adults in this play, a teacher has the tools to use play as the basis for curriculum". (Menyeimbangkan bermain dengan pekerjaan, menjadi kerangka penting untuk mengembangkan kurikulum dan lingkungan belajar anak-anak. Dengan pemahaman tentang teori dan tahapan bermain anak-anak dan interaksi dengan orang dewasa, dalam konteks ini guru memiliki alat untuk menggunakan bermain sebagai dasar untuk kurikulum). Hal ini sesuai dengan dunia anak yaitu dunia bermain. Secara alamiah bermain dapat memotivasi anak untuk mengetahui sesuatu yang lebih mendalam dan secara spontan anak mengembangkan kemampuan bahasa dari perbendaharaan huruf menjadi kata melalui apa yang mereka lihat dan terima dari guru maupun yang mereka temukan secara alamiah. Dengan bermain, anak mendapat kesempatan bereksperimen dan faktor menemukan sendiri, sangat membantu memahami konsep-konsep sesuai dengan perkembangan anak. Yus (2009:92) mengemukakan: "Bermain merupakan proses belajar baik disadari anak atau tidak anak telah belajar sesuatu yang berguna bagi hidupnya. Dengan demikian dapat dinyatakan bahwa bermain bagi anak sangat besar manfaatnya". Montessori dalam Sudono (2000:24) yang menekankan bahwa ketika anak bermain, ia akan mempelajari dan menyerap segala sesuatu yang terjadi di lingkungan sekitarnya.

Pengembangan pendidikan di TK bertujuan untuk mengembangkan keterampilan motorik halus dalam berolah tangan sehingga anak akan dapat menulis dengan baik. Program Kegiatan Belajar TK merupakan kegiatan belajar yang diberikan pada anak TK sebagai persiapan membaca dan menulis permulaan serta berhitung/ matematika. Kegiatan ini dibatasi pada usaha meletakkan dasar-dasar kesanggupan membaca, menulis dan berhitung/ matematika serta dilaksanakan melalui: (1) permainan; (2) nyanyian; (3) meng-ucapkan syair; (4) pengenalan menulis yang sebelumnya dikenalkan terlebih dahulu cara memegang pensil yang baik; dan (5) berhi-tung dengan cara melihat gambar atau media yang sesuai dengan minat anak. Budiningsih (2005:45) mengemukakan bahwa aplikasi teori kognitif dalam kegiatan pembelajaran, anak usia pra sekolah dan awal sekolah dasar akan dapat belajar dengan baik, terutama jika menggunakan benda-benda kongkrit. Masa usia TK merupakan tahun-tahun kehidupan yang sangat aktif. Anak mempunyai dorongan alamiah untuk bermain menggunakan seluruh panca indera dan kemampuannya.

Fenomena yang sering ditemukan pada masyarakat, sekolah TK melakukan metode pengajaran menulis dengan paksaan dan tanpa teknik sangat marak terjadi. Bahkan kadang dapat dijumpai pada sekolah yang awalnya menyampaikan konsep "bermain sambil belajar" tapi pada kenyataannya di lapangan juga tetap saja "belajar sambil bermain (belajar lebih banyak dan dominan)". Orangtua yang memiliki anak usia TK sering kali kebingungan memilih sekolah dan bagaimana seharusnya bersikap dan bertindak untuk pendidikan anak mereka. Di satu sisi kurikulum anak SD kelas 1 mengharuskan anak sudah bisa membaca dengan dasar mampu mengenal dan menulis huruf untuk dirangkaikan menjadi kata. Namun di sisi lain, orangtua yang sadar dan tidak ingin memaksa anaknya tetap dihadapkan pada kenyataan tersebut sehingga mau tidak mau mereka harus mengajarkan anaknya menulis dan membaca. Dari keadaan tersebut, banyak orangtua malah meminta bantuan guru les untuk mengajar anaknya. Pada kenyataannya konsep mengajar guru les belum tentu bisa sama sesuai dengan teknik mengajar guru di sekolah, sehingga anak belajar lebih dari satu konsep dan biasanya anak akan kebingungan mana yang harus mereka ikuti. Hal ini tentulah tidak baik untuk perkembangan anak. Anak-anak paling mudah meniru apa yang mereka lihat maupun yang mereka terima untuk pertama kali dan biasanya sangat bertahan lama dan sulit untuk diubah. Oleh karena itu pembelajaran pada usia dini sangatlah berperan penting untuk 
langkah selanjutnya dalam proses pembelajaran anak.

Hasil pengamatan penulis pada beberapa TK, diperoleh kesimpulan bahwa pada umumnya anak yang akan memasuki tingkat Sekolah Dasar belum memiliki keterampilan untuk menulis huruf sesuai dengan bentuk arah yang benar. Sebagian anak dalam tahun pertama sekolah formal tidak cukup hanya mengembangkan kemampuan motorik untuk membuat bentuk huruf dengan ukuran dan kerapian seperti yang diharapkan. Hal ini tentu saja tidak terlepas dari peranan guru dalam mengajar menulis karena dibutuhkan tingkat kesabaran yang lebih tinggi bila dibandingkan dengan mengajar materi lain. Menulis di TK merupakan langkah awal seorang anak untuk memiliki keterampilan dalam menulis. Awal yang baik tentu akan memberikan hasil yang baik juga. Oleh karena itu sangat dianjurkan kepada setiap guru TK memiliki konsep dan teknik yang baik untuk mengajarkan keterampilan menulis pada anak. Guru harus menguasai benar teknik menulis mana yang paling mudah dimengerti dan dipraktekkan oleh anak-anak. Kalimat-kalimat motivasi serta katakata yang berfungsi untuk menyimbolkan setiap goresan pada huruf juga sangat berperan penting di saat anak sedang mulai menulis. Jangan sampai dipikiran anak tertanam bahwa menulis adalah aktivitas yang paling sulit dan sangat ditakuti. Selain itu sering kali dijumpai juga urutan menulis huruf pada anak tidak dimulai dari huruf yang paling mudah, tetapi lebih ditekankan pada huruf pertama pada urutan abjad mulai dari "a" s/d "z". Padahal kalau dikaji kembali penulisan huruf " $a$ " juga sulit bagi anak yang baru mulai belajar memegang pensil dan belajar menulis.

Panjaitan (2011:122) mengemukakan pemahaman guru tentang karakteristik anak diharapkan tidak terjadi penetapan dan penerapan media yang tidak sesuai dengan cara belajar anak. Sejalan dengan pendapat ini, Latif, dkk, (2013:155) mengemukakan pemilihan media pembelajaran sangatlah penting. Diperlukan pengetahuan wawasan, pengetahuan dan keterampilan guru untuk dapat melakukannya dengan tepat, sehingga media yang diambil sesuai dengan kebutuhan dan perkembangan anak. Pada dasarnya pertimbangan untuk memilih suatu media sangatlah sederhana yaitu dapat memenuhi kebutuhan atau mencapai tujuan yang diinginkan atau tidak. Hal ini berarti seorang guru harus menyesuaikan media pembelajaran yang digunakannya dengan kondisi anak didik. Hamalik dalam Arsyad (2004:71) menyatakan bahwa pemakaian media pembelajaran dalam proses belajar dapat membangkitkan keinginan dan minat yang baru, membangkitkan motivasi dan rangsangan kegiatan belajar, dan bahkan membawa dampak psikologis terhadap peserta didik. Penggunaan media pembelajaran pada tahap orientasi pengajaran akan sangat membantu keefektifan proses pembelajaran.

Kurangnya pemanfaatan media pada kegiatan pembelajaran anak, khususnya untuk mengembangkan keterampilan menulis huruf. Dalam keterampilan menulis huruf, pada umumnya guru hanya mengandalkan spidol, papan flannel dan karton yang bergambar huruf. Sudono (2000:27) menyatakan bahwa praktek pendidikan anak saat ini mengandalkan kertas dan pensil, sehingga alokasi waktu terserap untuk kegiatan tersebut, yang berakibat evaluasi terhadap kemajuan anak hanya ditekankan pada kemampuan baca dan tulis saja.

Pada hakikatnya media pembelajaran khususnya untuk belajar menulis huruf belum banyak dikembangkan guru. Dalam kegiatan belajar menulis huruf di TK, guru hanya menggunakan media yang seadanya saja seperti spidol, buku yang menunjukkan gambar dan cara penulisan huruf yang instan tanpa memperkirakan tingkat kesulitan untuk setiap huruf dan hasilnya hanya memberikan rasa bosan dan tidak bertahan lama sebab anak-anak tidak dihadapkan pada suatu media pembelajaran yang dapat mengembangkan perkembangan kognitif anak untuk memahami pengertian atau konsep melalui benda yang nyata dan dapat dilihat langsung.

Oleh karena itu pada kesempatan ini penulis menggunakan suatu media yang dapat digunakan dalam kegiatan belajar TK. Media belajar yang coba ditawarkan penulis adalah media tepung huruf yang digunakan sedemikian rupa sebagai alat bermain sambil belajar serta untuk lebih menarik minat anak dalam menulis huruf. Dengan media tepung, seorang anak diberikan kesempatan untuk menulis di atas tepung dengan melihat petunjuk guru sesuai bentuk dan arah penulisan huruf.

Melalui media pembelajaran tepung huruf diharapkan mampu memberikan motivasi kepada anak agar tidak merasa takut, merasa sulit sebelum mencoba untuk menulis kembali huruf tersebut. Dengan adanya media ini anak dapat bermain sambil belajar tanpa harus 
langsung menggoreskan/ menggambarkan huruf dengan pensil di buku. Selain itu, dengan media tepung huruf kegiatan menulis huruf akan memberikan anak kesenangan bermain sambil belajar. Dengan media tepung, anak dapat menggambar dan menghapus huruf berulangulang sebagaimana ditunjukkan guru sehingga dapat memberi suasana bermain dalam diri anak yang sebenarnya inti kegiatan tersebut adalah belajar menulis huruf.

Heinich, dkk (1996:89) mengemu-kakan: "teacher-made drawings can be very effective teaching and learning devices. They can be drawn on the chalkboard (or some other appropriate surface) to coincide with specific aspects of the instructional unit. (Gambar buatan guru dapat mengajar sangat efektif dan perangkat pembelajaran. Gambar dapat dibuat di papan tulis (atau permukaan lain yang sesuai) dengan aspek-aspek tertentu dari unit pembelajaran). Dengan demikian, menggambar di atas tepung dapat digunakan dalam semua tahap instruksi, dari pengenalan tentang topik sampai evaluasi kegiatan menulis huruf. Sebab, dengan menuliskan huruf di atas tepung akan lebih bermakna dibanding hanya melihat bentuk huruf di media kartu. Hal ini akan mempermudah anak TK memahami bagaimana seharusnya suatu huruf ditulis.

Faktor lain yang juga akan dilihat pengaruhnya terhadap kemampuan menulis huruf adalah kreativitas anak. Kreativitas sebagai kemampuan umum untuk menciptakan sesuatu yang baru, gagasan-gagasan baru yang dapat diterapkan dalam pemecahan masalah dan untuk melihat hubungan-hubungan baru antara unsur-unsur yang telah ada. Menurut Buzan (2001:87) mengatakan bahwa masa usia TK, anak menggunakan 95\% - 98\% kreativitas untuk setiap kegiatan pembelajaran. Dengan demikian anak yang memiliki kreativitas tinggi cenderung memiliki kemampuan belajar yang baik. Berdasarkan uraian tersebut maka pada kesempatan ini penulis ingin mengetahui pengaruh media pembelajaran dan tingkat kreativitas terhadap kemampuan menulis huruf pada peserta didik TK Dr. Wahidin Sudirohusodo - Medan.

\section{METODE}

Penelitian dilakukan di TK Dr. Wahidin Sudirohusodo - Medan yang beralamat di Jalan Titi Pahlawan No. 8 Pasar V Medan Marelan. Penelitian ini direncana-kan pelaksanaannya di Tahun Ajaran 2013/2014, yakni pada bulan Januari 2014. Perlakuan pada masing-masing kelas dilakukan sebanyak 6 kali pertemuan sesuai jadwal pelajaran menulis huruf, dan untuk 1 kali pertemuan digunakan waktu 30 menit. Dengan demikian jumlah waktu pembelajaran menulis huruf pada masingmasing kelas adalah $6 \times 30$ menit. Populasi penelitian ini adalah seluruh peserta didik TK-B di TK Dr. Wahidin Sudirohusodo - Medan yang terdiri dari 9 (sembilan) kelompok belajar. Pengambilan sampel dengan menggunakan acak (cluster random sampling) melalui undian. Dalam hal ini yang menjadi sampel penelitian adalah kelas B6 dan B8 dengan jumlah sampel pada masing-masing kelas sebanyak 40 orang.

Penelitian ini menggunakan metode kuasi eksperimen (quasi experiment) dengan melakukan eksperimen di dalam kelas yang telah ada dan tidak melakukan perubahan situasi dan kondisi kelas serta jadwal belajarnya.

Rancangan penelitian ini mengguna-kan desain faktorial $2 \times 2$. Dimana melalui penelitian ini akan dibandingkan pengaruh antara media pembelajaran tepung huruf dan kartu huruf terhadap kemampuan menulis huruf anak TK ditinjau dari tingkat kreativitas tinggi dan kreativitas rendah. Media pembelajaran tepung huruf dan kartu huruf sebagai variabel bebas, kreativitas tinggi dan kreativitas rendah sebagai variabel bebas dan kemampuan menulis huruf sebagai variabel terikat. Adapun rancangan eksperimen dalam penelitian sebagaimana Tabel 1 berikut.

Tabel 1. Rancangan Penelitian Desain Faktorial $2 \times 2$

\begin{tabular}{|c|c|c|}
\hline $\begin{array}{c}\text { Kreativitas } \\
\text { (B) }\end{array}$ & $\begin{array}{c}\text { Media Tepung Huruf } \\
\text { (A1) }\end{array}$ & $\begin{array}{c}\text { Media Kartu Huruf } \\
\text { (A2) }\end{array}$ \\
\hline Kreativitas Tinggi $\left(\mathrm{B}_{1}\right)$ & $\mathrm{A}_{1} \mathrm{~B}_{1}$ & $\mathrm{~A}_{2} \mathrm{~B}_{1}$ \\
\hline Kreativitas Rendah $\left(\mathrm{B}_{2}\right)$ & $\mathrm{A}_{1} \mathrm{~B}_{2}$ & $\mathrm{~A}_{2} \mathrm{~B}_{2}$ \\
\hline
\end{tabular}




\section{HASIL}

Pengujian hipotesis dilakukan untuk membuktikan kebenaran hipotesis yang telah ditetapkan sehingga diperoleh apakah hipotesis yang dirancang dalam penelitian diterima atau ditolak. Untuk keperluan pengajuan hipotesis dengan menggunakan teknik analisis varians (ANAVA) faktorial 2 x 2 dan kemudian dilanjutkan dengan uji lanjut menggunakan Uji Tukey. Pada Tabel 2 disajikan rangkuman data kemampuan menulis huruf peserta didik sebagai sumber pengolahan data untuk pengujian hipotesis.

Tabel 2. Rangkuman Data Hasil Perhitungan Analisis Deskriptif

\begin{tabular}{|l|l|c|c|c|c|r|}
\hline $\begin{array}{c}\text { Media Pembelajaran } \\
\text { Kreativitas }\end{array}$ & \multicolumn{2}{|c|}{ Tepung Huruf } & \multicolumn{2}{|c|}{ Kartu Huruf } & \multicolumn{2}{|c|}{ Total } \\
\hline \multirow{5}{*}{ Tinggi } & $\mathrm{N}$ & 19 & $\mathrm{~N}$ & 20 & $\mathrm{~N}$ & 39 \\
\cline { 2 - 8 } & $\mathrm{X}$ & 1616 & $\mathrm{X}$ & 1449 & $\mathrm{X}$ & 3065 \\
\cline { 2 - 8 } & $\mathrm{X}^{2}$ & 138448 & $\mathrm{X}^{2}$ & 100531 & $\mathrm{X}^{2}$ & 238979 \\
\cline { 2 - 8 } & $\overline{\mathrm{X}}$ & 85,053 & $\overline{\mathrm{X}}$ & 69,000 & $\overline{\mathrm{X}}$ & 77,027 \\
\cline { 2 - 8 } & $\mathrm{s}$ & 7,465 & $\mathrm{~s}$ & 5,244 & $\mathrm{~s}$ & 6,355 \\
\hline \multirow{5}{*}{ Rendah } & $\mathrm{N}$ & 21 & $\mathrm{~N}$ & 20 & $\mathrm{~N}$ & 41 \\
\cline { 2 - 8 } & $\mathrm{X}$ & 1532 & $\mathrm{X}$ & 1391 & $\mathrm{X}$ & 2923 \\
\cline { 2 - 8 } & $\mathrm{X}^{2}$ & 118712 & $\mathrm{X}^{2}$ & 98569 & $\mathrm{X}^{2}$ & 217281 \\
\cline { 2 - 8 } & $\overline{\mathrm{X}}$ & 76,600 & $\overline{\mathrm{X}}$ & 69,550 & $\overline{\mathrm{X}}$ & 73,08 \\
\cline { 2 - 8 } & $\mathrm{s}$ & 8,463 & $\mathrm{~s}$ & 9,801 & $\mathrm{~s}$ & 9,132 \\
\hline \multirow{5}{*}{ Total } & $\mathrm{N}$ & 40 & $\mathrm{~N}$ & 40 & $\mathrm{~N}$ & 80 \\
\cline { 2 - 8 } & $\mathrm{X}$ & 3065 & $\mathrm{X}$ & 2923 & $\mathrm{X}$ & 5988 \\
\cline { 2 - 8 } & $\mathrm{X}^{2}$ & 238979 & $\mathrm{X}^{2}$ & 217281 & $\mathrm{X}^{2}$ & 456260 \\
\cline { 2 - 7 } & $\overline{\mathrm{X}}$ & 80,827 & $\overline{\mathrm{X}}$ & 69,275 & $\overline{\mathrm{X}}$ & 75,051 \\
\cline { 2 - 8 } & $\mathrm{s}$ & 7,964 & $\mathrm{~s}$ & 7,523 & $\mathrm{~s}$ & 7,743 \\
\hline
\end{tabular}

Sedangkan hasil analisis ringkasan analisis varians kemampuan menulis huruf dirangkum pada Tabel 3 berikut.

Tabel 3. Ringkasan Analisis Varians Kemampuan Menulis Huruf

\begin{tabular}{|l|r|r|r|r|r|l|}
\hline \multicolumn{1}{|c|}{ Sumber Varians } & \multicolumn{1}{c|}{$\mathbf{d k}$} & \multicolumn{1}{c|}{ JK } & RJK & $\mathbf{F}_{\text {hitung }}$ & $\begin{array}{c}\mathbf{F}_{\text {tabel }} \\
(\boldsymbol{\alpha}=\mathbf{5 \%})\end{array}$ & Ket \\
\hline Media Pembelajaran (A) & 1 & 252,050 & 252,050 & 4,042 & 3,96 & Signifikan \\
\hline Kreativitas (B) & 1 & 2620,254 & 2620,254 & 42,024 & 3,96 & Signifikan \\
\hline Interaksi(AB) & 1 & 447,199 & 447,199 & 7,172 & 3,96 & Signifikan \\
\hline Galat & 76 & 4738,697 & 62,351 & - & - & \\
\hline Total & 79 & 8058,200 & - & - & - & \\
\hline
\end{tabular}

Berdasarkan hasil perhitungan pada Tabel 3 diperoleh perbedaan kemampuan menulis huruf peserta didik kelas media pembelajaran tepung huruf dengan kemampuan menulis huruf kelas peserta didik media pembelajaran kartu huruf. Besar nilai $\mathrm{F}_{\text {hitung }}=4,042$, sedangkan nilai $\mathrm{F}_{\text {tabel }}$ dengan $\mathrm{dk}$ $(3,74)$ pada taraf signifikansi $5 \%$ adalah 3,96. Hasil ini menunjukkan bahwa $\mathrm{F}_{\text {hitung }}>\mathrm{F}_{\text {tabel }}$ $(4,042>3,96)$, sehingga memberikan keputusan menolak Ho dan menerima Ha. Dengan demikian dapat disimpulkan bahwa hipotesis penelitian yang menyatakan bahwa ada perbedaan kemampuan menulis huruf peserta didik kelas media pembelajaran tepung huruf dengan kemampuan menulis huruf peserta didik kelas media pembelajaran kartu huruf teruji kebenarannya. Hasil perhitungan pada Tabel 3 diperoleh perbedaan kemampuan menulis huruf peserta didik yang memiliki kreativitas tinggi dengan kemampuan menulis huruf peserta didik yang memiliki kreativitas rendah. Besar nilai $F_{\text {hitung }}$ $=42,024$, sedangkan nilai $F_{\text {tabel }}$ dengan $\mathrm{dk}$ $(3,74)$ pada taraf signifikansi $5 \%$ adalah 3,96 . Hasil ini menunjukkan bahwa $F_{\text {hitung }}>F_{\text {tabel }}$ $(42,024>3,96)$, sehingga memberikan keputusan menolak Ho dan menerima Ha. 
Dengan demikian dapat disimpulkan bahwa hipotesis penelitian yang menyatakan bahwa ada perbedaan kemampuan menulis huruf peserta didik berkreativitas tinggi dengan kemampuan menulis huruf peserta didik berkreativitas rendah teruji kebenarannya.

Selanjutnya pada Tabel 3 diperoleh interaksi antara media pembelajaran dan kreativitas terhadap kemampuan menulis huruf peserta didik. Besar nilai $F_{\text {hitung }}=7,172$, sedangkan nilai $\mathrm{F}_{\text {tabel }}$ dengan $\mathrm{dk}(3,74)$ pada taraf signifikansi 5\% adalah 3,96. Hasil ini menunjukkan bahwa $F_{\text {hitung }}>F_{\text {tabel }}(7,172>$ 3,96), sehingga memberikan keputusan menolak Ho dan menerima Ha. Dengan demikian dapat disimpulkan bahwa hipotesis penelitian yang menyatakan bahwa ada interaksi antara media pembelajaran dan kreativitas terhadap kemampuan menulis huruf peserta didik teruji kebenarannya. Interaksi media pembelajaran dan kreativitas terhadap kemampuan menulis huruf peserta didik dapat digambarkan sebagaimana Gambar 1 berikut.

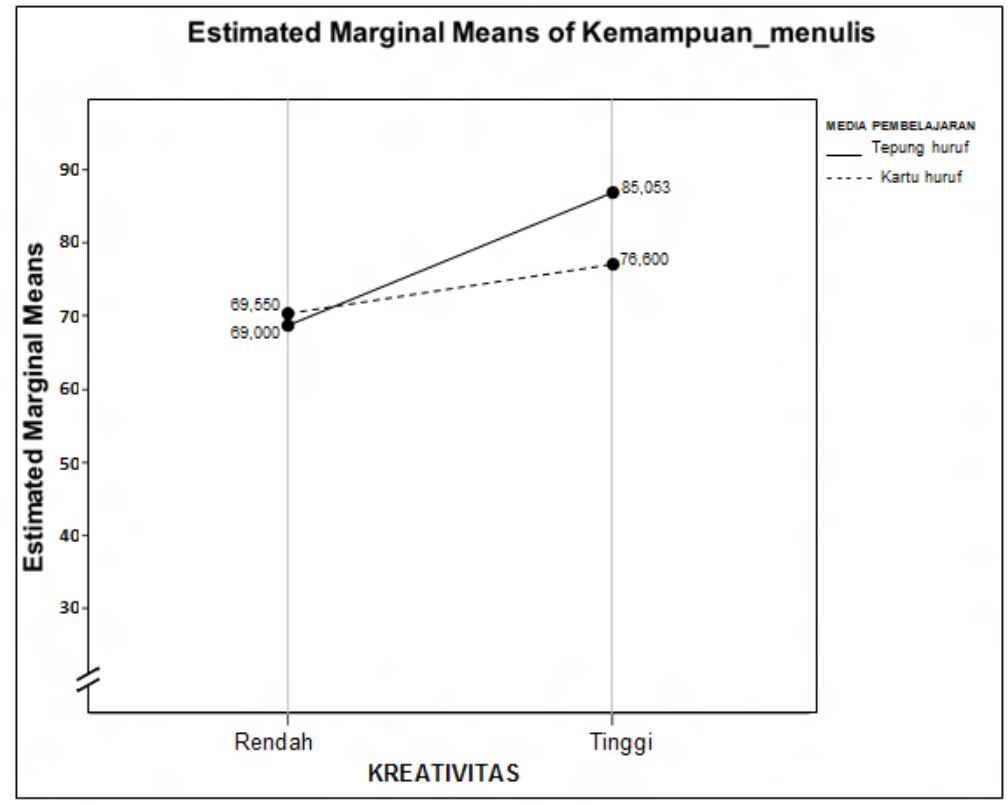

Gambar 1. Garis Interaksi Media Pembelajaran dan Kreativitas terhadap Kemampuan Menulis Huruf Peserta Didik

Pada Gambar 1 terlihat ada interaksi antara media pembelajaran dan kreativitas terhadap kemampuan menulis huruf peserta didik, yang ditunjukkan dengan adanya titik perpotongan antara garis kreativitas tinggi dan rendah dari masing-masing kelas perlakuan. Selanjutnya dengan adanya interaksi antara media pembelajaran dan kreativitas terhadap kemampuan menulis huruf, dilakukan uji lanjutan dengan menggunakan Uji Tukey. Dari Uji Tukey diperoleh hasil sebagai berikut:

1. Perbedaan kemampuan menulis huruf kelas media pembelajaran tepung huruf dengan kemampuan menulis huruf kelas media pembelajaran kartu huruf. Dari hasil perhitungan dengan Uji Tukey menunjukkan bahwa $F_{\text {hitung }}=4,020$. Untuk nilai distribusi $\mathrm{F}_{\text {tabel }}$ dengan dk $(3,36)$ pada taraf signifikan $5 \%=3,49$. Hasil ini menunjukkan bahwa $F_{\text {hitung }}>F_{\text {tabel }}(4,020>$ 3,49 ), sehingga memberikan keputusan bahwa kemampuan menulis huruf kelas media pembelajaran tepung huruf memiliki perbedaan yang berarti dengan kemampuan menulis huruf kelas media pembelajaran kartu huruf.

2. Perbedaan kreativitas media pembelajaran tepung huruf dengan kreativitas kelas media pembelajaran kartu huruf. Dari hasil perhitungan dengan Uji Tukey menunjukkan bahwa $F_{\text {hitung }}=4,643$. Untuk nilai distribusi $\mathrm{F}_{\text {tabel }}$ dengan $\mathrm{dk}(3,36)$ pada taraf signifikan $5 \%=3,49$. Hasil ini menunjukkan bahwa $F_{\text {hitung }}>F_{\text {tabel }}(4,643>$ 3,49 ), sehingga memberikan keputusan bahwa kreativitas kelas media pembelajaran tepung huruf memiliki perbedaan yang berarti dengan kreativitas kelas media pembelajaran kartu huruf. 
3. Perbedaan kemampuan menulis huruf kelas media pembelajaran tepung huruf yang memiliki kreativitas tinggi dengan kemampuan menulis huruf kelas media pembelajaran tepung huruf yang memiliki kreativitas rendah. Dari hasil perhitungan dengan Uji Tukey menunjukkan bahwa $F_{\text {hitung }}=18,183$. Untuk nilai distribusi $F_{\text {tabel }}$ dengan $\mathrm{dk}(3,36)$ pada taraf signifikan $5 \%$ $=3,49$. Hasil ini menunjukkan bahwa $\mathrm{F}_{\text {hitung }}>\mathrm{F}_{\text {tabel }}(18,183>3,49)$, sehingga memberikan keputusan bahwa kemampuan menulis huruf peserta didik kelas media pembelajaran tepung huruf yang memiliki kreativitas tinggi memiliki perbedaan yang berarti dengan kemampuan menulis huruf peserta didik kelas media pembelajaran tepung huruf yang memiliki kreativitas rendah.

4. Perbedaan kemampuan menulis huruf kelas media pembelajaran kartu huruf yang memiliki kreativitas tinggi dengan kemampuan menulis huruf kelas media pembelajaran kartu huruf yang memiliki kreativitas rendah. Dari hasil perhitungan dengan Uji Tukey menunjukkan bahwa $F_{\text {hitung }}=7,986$. Untuk nilai distribusi $F_{\text {tabel }}$ dengan $\mathrm{dk}(3,36)$ pada taraf signifikan $5 \%$ $=3,49$. Hasil ini menunjukkan bahwa $F_{\text {hitung }}>F_{\text {tabel }}(7,986>3,49)$, sehingga memberikan keputusan bahwa kemampuan menulis huruf peserta didik kelas media pembelajaran kartu huruf yang memiliki kreativitas tinggi memiliki perbedaan yang berarti dengan kemampuan menulis huruf peserta didik kelas media pembelajaran kartu huruf yang memiliki kreativitas rendah.

5. Perbedaan kemampuan menulis huruf kelas media pembelajaran tepung huruf yang memiliki kreativitas tinggi dengan kemampuan menulis huruf kelas media pembelajaran kartu huruf yang memiliki kreativitas tinggi. Dari hasil perhitungan dengan Uji Tukey menunjukkan bahwa $F_{\text {hitung }}=9,574$. Untuk nilai distribusi $F_{\text {tabel }}$ dengan dk $(3,99)$ pada taraf signifikan $5 \%$ $=3,49$. Hasil ini menunjukkan bahwa $\mathrm{F}_{\text {hitung }}>\mathrm{F}_{\text {tabel }}(9,574>3,49)$, sehingga memberikan keputusan bahwa kemampuan menulis huruf peserta didik kelas media pembelajaran tepung huruf yang memiliki kreativitas tinggi memiliki perbedaan yang berarti dengan kemampuan menulis huruf peserta didik kelas media pembelajaran kartu huruf yang memiliki kreativitas tinggi.

6. Perbedaan kemampuan menulis huruf kelas media pembelajaran tepung huruf yang memiliki kreativitas rendah dengan kemampuan menulis huruf kelas media pembelajaran kartu huruf yang memiliki kreativitas rendah. Dari hasil perhitungan dengan Uji Tukey menunjukkan bahwa $\mathrm{F}_{\text {hitung }}=3,744$. Untuk nilai distribusi $\mathrm{F}_{\text {tabel }}$ dengan dk $(3,99)$ pada taraf signifikan $5 \%$ $=3,49$. Hasil ini menunjukkan bahwa $\mathrm{F}_{\text {hitung }}<\mathrm{F}_{\text {tabel }}(0,623<3,49)$, sehingga memberikan keputusan bahwa kemampuan menulis huruf peserta didik kelas media pembelajaran tepung huruf yang memiliki kreativitas rendah tidak memiliki perbedaan yang berarti dengan kemampuan menulis huruf peserta didik kelas media pembelajaran kartu huruf yang memiliki kreativitas rendah.

\section{Pembahasan}

\section{Perbedaan kemampuan menulis huruf} peserta didik kelas media pembelajaran tepung huruf dengan kemampuan menulis huruf peserta didik kelas media pembelajaran kartu huruf

Peserta didik dapat menulis huruf dengan baik jika mampu melihat bentukbentuk huruf yang jelas, mampu menggerakkan mata secara lincah, mengingat simbol-simbol huruf dengan tepat serta memiliki penalaran yang cukup untuk memahami setiap huruf yang akan ditulis. Salah satu pola pembelajaran yang dapat digunakan guru adalah dengan menggunakan metode bermain sambil belajar. Fadillah (2012:169) menyatakan "metode bermain yang dilakukan dalam kegiatan pembelajaran tidak hanya akan disukai anak-anak usia dini, tetapi juga sangat bermanfaat bagi perkembangan anak. Untuk itu, ada baiknya bila metode bermain diaplikasi pada pembelajaran anak usia dini".

Hasil penelitian menunjukkan bahwa kemampuan menulis huruf peserta didik pada media pembelajaran tepung huruf berbeda dengan media pembelajaran kartu huruf, yang ditunjukkan rata-rata nilai kemampuan menulis huruf kelas media pembelajaran tepung huruf lebih tinggi dari rata-rata nilai kemampuan menulis huruf kelas media pembelajaran 
kartu huruf $(76,625>73,075)$. Selain itu dari media pembelajaran tepung huruf memberikan hasil kemampuan menulis huruf peserta didik yang tergolong sangat baik sebanyak 7 orang $(17,5 \%)$, baik 9 orang $(22,5 \%)$, cukup 9 orang $(22,5 \%)$, kurang 13 orang $(32,5 \% 0$, dan tidak baik 2 orang $(5,0 \%)$. Sedangkan kemampuan menulis huruf kelas media pembelajaran kartu huruf untuk kategori sangat baik sebanyak 1 orang $(2,5 \%)$, baik 8 orang $(8,0 \%)$, cukup 16 orang $(16,0 \%)$, kurang 12 orang $(12,0 \% 0$, dan tidak baik 3 orang $(7,5 \%)$.

Kemampuan menulis huruf peserta didik dikatakan sangat baik bila menunjukkan hal-hal sebagai berikut: (1) mampu menunjukkan hasil belajar dalam bentuk tulisan, urutan menulis, arah tulisan, dan tekanan tulisan dengan sangat baik. Pada bagian ini peserta didik mampu menulis kembali huruf yang diberikan pada lembar kerja sesuai dengan contoh yang diberikan guru;

(2) mampu menyebutkan hasil kerja dalam bentuk lafal huruf dan lafal kata dengan sangat baik. Pada bagian ini peserta didik mampu melafalkan kembali huruf yang ditulisnya dengan tepat; dan (3) mampu menggunakan alat-alat belajar dalam bentuk koordinasi jari tangan, kecepatan menulis, dan gestur tubuh saat menulis dengan sangat baik. Pada bagian ini peserta didik mampu menggunakan alat belajar namun belum digunakan sesuai dengan fungsinya.

Sedangkan kemampuan anak dikatakan tidak baik bila menunjukkan halhal sebagai berikut: (1) tidak mampu menunjukkan hasil belajar dalam bentuk tulisan, urutan menulis, arah tulisan, dan tekanan tulisan dengan sangat baik. Pada bagian ini peserta didik hanya mampu menulis kembali huruf yang diberikan pada lembar kerja dengan bentuk yang belum jelas; (2) tidak mampu menyebutkan hasil kerja dalam bentuk lafal huruf dan lafal kata dengan sangat baik. Pada bagian ini peserta didik tidak mampu melafalkan kembali huruf yang telah ditulisnya; dan (3) tidak mampu menggunakan alat-alat belajar dalam bentuk koordinasi jari tangan, kecepatan menulis, dan gestur tubuh saat menulis dengan sangat baik. Pada bagian ini peserta didik hanya mau menggunakan alat belajar namun belum digunakan sesuai dengan fungsinya.

Hasil penelitian ini juga mendukung penelitian yang dilakukan Mulia (2012) dan Haezarni (2011) bahwa ada perbedaan hasil belajar yang disebabkan oleh penggunaan media pembelajaran yang tepat sesuai kemampuan anak. Melalui bermain akan mengaktifkan semua kemampuan anak, termasuk kemampuan menulis huruf. Dengan bermain anak tidak merasa terbebani, anak merasa nyaman dan rileks padahal sebenarnya dia sedang belajar. Von Aufshnaiter \& Schwedes (dalam Seefeldt dan Nita, 1994:313) menyatakan "Children learn as they move between work and play. Some researchers maintain that meaningful learning occurs mainly in play situations or in situations where children transform nonplay situations into play".

Dengan demikian, pembelajaran yang paling efektif pada anak usia dini adalah dengan bermain. Hasil penelitian Vygotsky (dalam Hughes, 2010:214) mengemukakan: "The value of play materials is that they help children separate themselves from concrete reality and distinguish between actual objects and what they are intended to represent. Representational ability is, of course, a central characteristic of intellectual functioning in early childhood, and symbolic play is the most cognitively dependent of all forms of play". Media tepung huruf akan merangsang peserta didik menjadi aktif dalam proses kemampuan menulis huruf. Belajar menjadi mudah dengan lebih dahulu menyajikan urutan huruf yang paling mudah ditulis dengan menggoreskannya di atas tepung sebelum dilanjutkan dengan menulis di buku. Keinginan anak untuk menuliskan huruf di atas bahan tepung akan memberikan sensasi pada jari sehingga dapat merasakan kontrol jarinya dan membentuk konsep gerak membuat huruf. Selain itu dengan menuliskan huruf di atas tepung akan melatih pengembangan imajinasi, memperhalus kemampuan motorik halus, dan mengasah kemampuan menulis anak. Selain itu, cara kerja melalui media tepung huruf mampu merangsang 
kerja otak peserta didik serta kegiatan pembelajaran yang tidak monoton.

\section{Perbedaan kemampuan menulis huruf} peserta didik yang memiliki kreativitas tinggi dengan kemampuan menulis huruf peserta didik yang memiliki kreativitas rendah

Penguasaan kemampuan menulis huruf pada peserta didik TK dipengaruhi oleh banyak faktor baik intelegensi, bakat, minat, motivasi maupun kreativitas yang ada di dalam diri. Untuk peserta didik TK, kreativitas merupakan modal dasar dalam melakukan aktivitas belajar. Dengan kemampuan kreativitas yang tinggi, anak dapat mengembangkan kemampuan belajar secara maksimal. Ali (2009:151) menyatakan bahwa kreativitas membuka pikiran dan menjadikan motivasi hidup lebih tinggi, karena tidak takut kehilangan peluang. Anak kreatif dapat menciptakan peluang sendiri, sehingga tidak takut menghadapi masalah, karena memiliki kemampuan menyelesaikan masalah yang tinggi.

Hasil penelitian menunjukkan bahwa kemampuan menulis huruf peserta didik yang memiliki kreativitas tinggi berbeda dengan kreativitas rendah, yang ditunjukkan rata-rata nilai kemampuan menulis huruf kreativitas tinggi lebih baik dari rata-rata nilai kemampuan menulis huruf kreativitas rendah $(81,897>69,732)$. Kreativitas anak dikategorikan tinggi bila menunjukkan hal-hal sebagai berikut: (1) kelancaran (fluency), yaitu peserta didik dapat membuat gambar dalam jumlah yang cukup banyak, dan berurutan dari gambar yang mudah ke sukar; (2) keluwesan (flexibility), yaitu bila gambar peserta didik mempunyai bentuk yang utuh dan rapi; (3) keaslian (originality), yaitu adanya kejelasan dari gambar yang dibuat dan tidak terdapat pengulangan gambar; (4) keterperincian (elaboration), yaitu bila ada ornamen spesifik yang ditambahkan pada gambar; dan (5) kepekaan (sensitivity), yaitu bila gambar memiliki keunikan tersendiri atau berbeda dari bentuk gambar secara umum.

Sedangkan kreativitas anak dikategorikan rendah bila menunjukkan hal-hal sebagai berikut: (1) kelancaran (fluency), yaitu peserta didik hanya dapat membuat gambar dengan jumlah sedikit dan tidak berurutan; (2) keluwesan (flexibility), yaitu bila gambar peserta didik tidak mempunyai bentuk yang utuh dan rapi (asal jadi); (3) keaslian (originality), yaitu gambar yang dihasilkan tidak jelas bentuknya dan selalu berulang; (4) keterperincian (elaboration), yaitu bila tidak ada ornamen spesifik pada gambar; dan (5) kepekaan (sensitivity), yaitu bila gambar tidak berbeda dari bentuk gambar secara umum.

Hasil penelitian ini mendukung penelitian yang dilakukan Jainab (2004:81) bahwa kemampuan menulis anak TK dipengaruhi oleh tingkat kreativitasnya. Dengan demikian, kreativitas dapat membantu peserta didik mempelajari kemampuan menulis huruf. Hal ini dikarenakan kemampuan menulis huruf membutuhkan kemampuan peserta didik dalam menangkap, mengingat, memahami, dan membedakan cara penulisan huruf sesuai dengan urutan dan cara penulisan yang mudah dilakukan oleh anak. Bila anak memiliki tingkat kreativitas tinggi dapat diartikan bahwa anak memiliki kemampuan yang baik dalam berpikir sehingga kegiatan belajar menulis huruf dapat diikuti dengan mudah.

Selain itu, kreativitas pada seorang anak memberikan kemampuan untuk melahirkan sesuatu yang baru, baik berupa gagasan maupun karya nyata yang relatif berbeda dengan apa yang telah ada. Dengan tingkat kreativitas yang tinggi, anak akan berlatih melakukan kombinasi atau sesuatu yang baru berdasarkan data, informasi, atau unsur-unsur yang telah ada untuk menyelesaikan masalah dengan cara yang khas.

\section{Interaksi antara media pembelajaran dan kreativitas terhadap kemampuan menulis huruf peserta didik TK}

Kemampuan menulis huruf pada anak membutuhkan aktivitas kompleks, karena kegiatan menulis bersifat kompleks karena tidak hanya melibatkan otak sebagai pusat pengolah informasi, tetapi melibatkan berbagai indera dan serangkaian gerakan-gerakan motorik. Secara lateral, otak manusia terbagi atas otak kanan dan otak kiri. Keduanya memiliki fungsi yang berbeda saat 
digunakan untuk mengolah informasi yang diterimanya. Menulis adalah salah satu kegiatan yang melibatkan kerjasama dan hubungan timbal-balik antara dua belahan otak tersebut

Untuk mendapatkan kemampuan menulis anak yang terbaik, seorang guru harus dapat memahami setiap anak didiknya. Guru harus paham bagaimana kemampuan anak dalam memahami materi dan bagaimana kreativitas setiap anak didik. Hal ini bertujuan agar guru dapat menggunakan media pembelajaran yang tepat mencapai tujuan belajar anak, yakni mampu dalam membuat huruf secara tepat sesuai urutan penulisannya.

Salah satu bentuk media yang dapat digunakan guru adalah media tepung huruf. Dengan menggunakan media tepung huruf, setiap anak akan merasakan sensasi pada jarinya ketika menuliskan huruf di atas tepung. Sensasi yang dirasakan anak akan mempermudahnya dalam menuliskan huruf kembali di atas kertas. Hal ini memberikan kemudahan pada guru dalam mengajarkan cara menulis huruf dengan tepat. Selain itu, dengan media pembelajaran tepung huruf kreativitas anak dapat dikembangkan ke arah yang lebih baik lagi. Runco (dalam Hughes, 2010:229) menyatakan: "Creative children display evidence of persistence, high energy, self-confidence, independence of judgement, flexibility, openness to new experiences, tolerance of ambiguity, and a good sense of humor. In addition, they seem to be aware of and accepting of their own feeling and playfully curious about the world".

Anak yang memiliki tingkat kreativitas tinggi seperti yang telah disampaikan sebelumnya mampu menyelesaikan kesulitan yang dihadapi dalam kegiatan pembelajaran dengan baik sehingga anak tidak merasa kesulitan walaupun menggunakan media yang lain. Sebaliknya apabila tingkat kreativitas anak rendah maka tidak mudah bagi mereka untuk menyelesaikan kesulitan yang dihadapi dalam mengikuti kegiatan pembelajaran dengan media. Anak yang memiliki kreativitas rendah masih harus mendapatkan bimbingan dan arahan dari guru.
Pengembangan kreativitas pada anak TK dapat dilakukan melalui kegiatan belajar yang menggunakan media konkrit, dengan tujuan mengembangkan berbagai aspek perkembangan anak. Dengan penggunaan media konkrit (tepung), tidak hanya kreativitas yang terfasilitasi untuk berkembang dengan baik, tetapi juga kemampuan kognitif anak. Media tepung huruf dapat dijadikan sebagai salah satu upaya pembelajaran yang dirancang untuk meningkatkan kreativitas anak mencapai kemampuan anak dalam menulis huruf baik. Dalam hal ini pembelajaran menggunakan tepung huruf bagi anak yang memiliki tingkat kreativitas rendah dapat membantu meningkatkan kreativitas belajarnya. Hal ini dikarenakan nilai strategis media tepung huruf dapat menimbulkan motivasi dan daya tarik untuk memenuhi fungsi bermain. Dengan demikian setiap anak akan beranggapan bahwa media tepung huruf sebagai media permainan yang sebenarnya tujuan utama dari media tepung huruf ini adalah agar anak berani menggoreskan huruf yang diajarkan guru sebelum menulis di buku. Media tepung huruf ini tentu memudahkan bagi anak untuk menyerap pesan yang akan disampaikan guru karena sambil bermain mereka juga telah belajar.

Selain itu, setiap anak akan menggunakan imajinasinya dalam kegiatannya untuk membentuk suatu huruf atau benda tertentu sesuai dengan khayalannya. Dalam hal ini setiap anak bebas mengekspresikan kreativitasnya dalam membuat huruf di atas tepung. Selain itu, penggunaan media tepung huruf akan lebih baik dalam mengatasi kesulitankesulitan guru dalam mengajar baik bagi anak yang memiliki kreativitas tinggi maupun anak yang memiliki kreativitas rendah sehingga dapat mengoptimalkan kemampuan menulis huruf anak.

\section{PENUTUP \\ Simpulan}

Berdasarkan hasil penelitian yang telah diuraikan pada Bab IV, maka dapat disimpulkan:

1. Terdapat perbedaan kemampuan menulis huruf kelas media pembelajaran tepung huruf dengan kemampuan menulis huruf kelas media pembelajaran kartu huruf pada 
peserta didik TK Dr. Wahidin Sudirohusodo - Medan.

2. Terdapat perbedaan kemampuan menulis huruf peserta didik yang memiliki kreativitas tinggi dengan kemampuan menulis huruf peserta didik yang memiliki kreativitas rendah pada peserta didik TK Dr. Wahidin Sudirohusodo - Medan.

3. Terdapat interaksi antara media pembelajaran dan kreativitas terhadap kemampuan menulis huruf pada peserta didik TK Dr. Wahidin Sudirohusodo Medan.

\section{Implikasi}

Implikasi penelitian dapat diberikan

berdasarkan hasil penelitian dan kesimpulan penelitian, di antaranya:

1. Dengan diterimanya hipotesis pertama yang diajukan, yakni terdapat perbedaan kemampuan menulis huruf kelas media pembelajaran tepung huruf dengan kemampuan menulis huruf kelas media pembelajaran kartu huruf pada peserta didik TK Dr. Wahidin Sudirohusodo Medan. Untuk itu perlu dilakukan upaya dalam pengembangan pembelajaran di kelas dengan menggunakan media pembelajaran tepung huruf dalam meningkatkan kemampuan peserta didik menulis huruf. Dengan media pembelajaran tepung huruf, anak akan merasakan sensasi cara menulis huruf dengan tepat sebelum memindahkannya ke buku catatan. Penggunaan media pembelajaran tepung huruf harus terus dikembangkan mengingat kesimpulan penelitian menyatakan bahwa kemampuan menulis peserta didik yang diajarkan dengan media pembelajaran tepung huruf lebih baik dibanding dengan media kartu huruf.

2. Dengan diterimanya hipotesis kedua yang diajukan, yakni terdapat terdapat perbedaan kemampuan menulis huruf peserta didik yang memiliki kreativitas tinggi dengan kemampuan menulis huruf peserta didik yang memiliki kreativitas rendah pada peserta didik TK Dr. Wahidin Sudirohusodo - Medan. Untuk itu perlu dilakukan upaya dalam meningkatkan kreativitas peserta didik dalam belajar. Tingkat kreativitas peserta didik mempengaruhi cara dirinya menerima, menalar, dan mempraktekkan bagaimana cara menulis huruf dengan tepat. Peningkatkan kreativitas peserta didik dapat dilakukan dengan memberikan rangsangan kreatif kepada anak dalam bentuk permainan belajar dan sebagainya. Kreativitas peserta didik dalam belajar harus terus ditingkatkan mengingat kesimpulan penelitian yang menyatakan bahwa kemampuan menulis huruf pada peserta didik yang memiliki kreativitas tinggi lebih baik daripada peserta didik yang memiliki kreativitas rendah.

3. Dengan diterimanya hipotesis ketiga yang diajukan, yakni terdapat terdapat interaksi antara media pembelajaran dan kreativitas terhadap kemampuan menulis huruf pada peserta didik TK Dr. Wahidin Sudirohusodo - Medan. Hal ini menggambarkan bahwa ada keterkaitan antara media pembelajaran yang digunakan guru dengan tingkat kreativitas anak. Penggunaan media pembelajaran yang dapat memaksimalkan kemampuan anak, baik pada anak yang memiliki kreativitas tinggi maupun rendah akan sangat membantu dalam pencapaian tujuan belajar. Hal ini harus terus dikembangkan mengingat kesimpulan penelitian yang menyatakan bahwa ada interaksi antara media pembelajaran dan kreativitas dengan kemampuan menulis huruf pada peserta didik.

\section{Saran}

Berdasarkan kesimpulan, maka dapat diberikan beberapa saran sebagai berikut:

1. Untuk dapat meningkatkan kemampuan menulis huruf pada peserta didik perlu dilakukan upaya dengan menggunakan media pembelajaran tepung huruf. Penggunaan media tepung huruf dalam pembelajaran di kelas dapat dilakukan dengan: (a) mengharuskan guru kelas menggunakan media pembelajaran tepung huruf dalam pembelajaran menulis huruf, (b) pihak sekolah harus menyediakan peralatan belajar yang dipakai untuk menggunakan media pembelajaran tepung huruf, dan $\quad$ (c) melaksanakan pelatihan penggunaan media tepung huruf kepada seluruh guru kelas.

2. Untuk dapat meningkatkan kreativitas pada peserta didik perlu dilakukan upaya sebagai berikut: (a) melakukan pembelajaran yang melatih peserta didik 
untuk terus kreatif dan terlibat aktif, dan (b) sekolah memfasilitasi keberadaan psikolog untuk memantau dan membina kreativitas peserta didik di sekolah.

3. Perlu diadakan penelitian yang lebih lanjut tentang keterkaitan kemampuan menulis huruf anak didik ditinjau dari penggunaan media pembelajaran dan kreativitas peserta didik.

\section{DAFTAR PUSTAKA}

Aqib, Zainal. 2013. Model-Model, Media, dan Strategi Pembelajaran Kontekstual (Inovatif). Bandung: Yrama Widya

Budiningsih, C. Asri. 2005. Belajar dan Pembelajaran. Jakarta: Rineka Cipta

Buzan. 2001. 10 Cara Jadi Orang Jenius Kreatif. Jakarta: Gramedia Pustaka Utama

Dryden dan Vos. 2001. Revolusi Cara Belajar. Bandung: Mizan Media Utama

Fadillah, Muhammad. 2012. Desain Pembelajaran PAUD: Tinjauan Teoritik dan Praktik. Jogjakarta: Ar-Ruzz Media

Hamid, Sholeh. 2011. Metode Edu Tainment. Jogjakarta: DIVA Press

Heinich, Robert., Michael Molenda, dan James D. Russell. 1996. Intructional Media and The New Technologies of Instruction. United State of Amerika: SAGE Publications, Inc.

Latif, Mukhtar. Rita Zubaidah, Zukhairina, dan Muhammad Afandi. 2013. Orientasi Baru Pendidikan Anak Usia Dini: Teori dan Aplikasi. Jakarta: Kencana

Panjaitan, Keysar. 2011. "Media Pembelajaran Yang Menyenangkan". Jurnal Teknologi Pendidikan Vol. 4 No. 2
Halaman 122-126, Oktober 2011. Medan: Program Studi Teknologi Pendidikan Pascasarajana Universitas Negeri Medan

Patmonodewo. 2003. Pendidikan Anak Pra Sekolah. Jakarta: Rineka Cipta

Peraturan Menteri Pendidikan Nasional Republik Indonesia Nomor 58 Tahun 2009 tentang Standar Pendidikan Anak Usia Dini

Peraturan Pemerintah Nomor 17 Tahun 2010 tentang Pengelolaan dan Penyelenggaraan Pendidikan

Seefeldt, Carol dan Barbara A. Wasik. 2008. Pendidikan Anak Usia Dini. Jakarta: Indeks

Seefeldt, Carol dan Nita Barbour. 1994. Early Childhood Education: An Introduction $3^{\text {rd }}$ Edition. United State of Amerika: MacMillan Publishing Company

Semiawan, Conny. 2002. Belajar dan Pembelajaran dalam Taraf Usia Dini Pendidikan Pra Sekolah dan Sekolah Dasar. Jakarta: Prehalindo

Sudjana, Nana. 1998. Hasil Penelitian dan Pendidikan. Jakarta: Rineka Cipta

Sudono. 2000. Sumber Belajar dan Alat Permainan untuk Pendidikan Anak Usia Dini. Jakarta: Gramedia

Undang-Undang Nomor 20 Tahun 2003 tentang Sistem Pendidikan Nasional

Yus, Anita. 2009. "Bermain dan Pembelajaran Anak Usia Dini”. Jurnal Teknologi Pendidikan Vol. 2 No. 1 Halaman 1-99, April 2009. Medan: Program Studi Teknologi Pendidikan Pascasarajana Universitas Negeri Medan 